\section{Antifungal cyclic peptides from the marine sponge Microscleroderma herdmani. [Corrigendum]}

Zhang X, Jacob MR, Ranga Rao R, Wang YH, Agarwal AK, Newman DJ, Khan IA, Clark AM, Li XC. Antifungal cyclic peptides from the marine sponge Microscleroderma herdmani. Research and Reports in Medicinal Chemistry. 2012;2:7-14.

The authors request the corrections of the structural drawing for the compounds in Figures 1 and 3.

The structures of the known compounds microsclerodermins A (3) and B (4) are corrected in Figure 1.

The stereochemistry of the pyrrolidone amino acid in the new compounds microsclerodermins J (3) and K (4) is changed to be the same as microsclerodermins A (3) and B (4) in Figures 1 and 3.

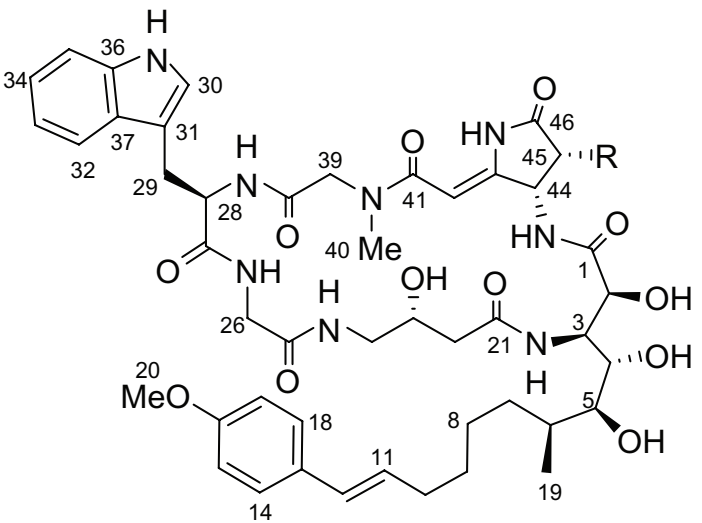

$\mathrm{R}$

$1 \mathrm{H}$

$2 \mathrm{OH}$

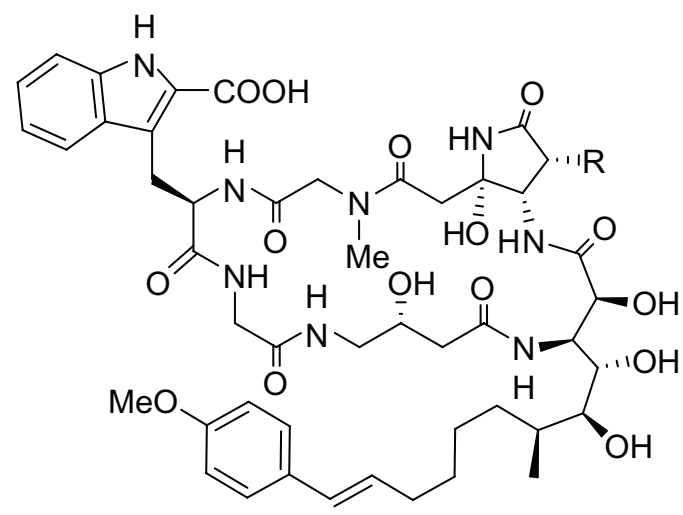

$\mathrm{R}$

$3 \mathrm{OH}$

$4 \mathrm{H}$

Figure I. Structures of compounds I-4.

submit your manuscript | www.dovepress.com 


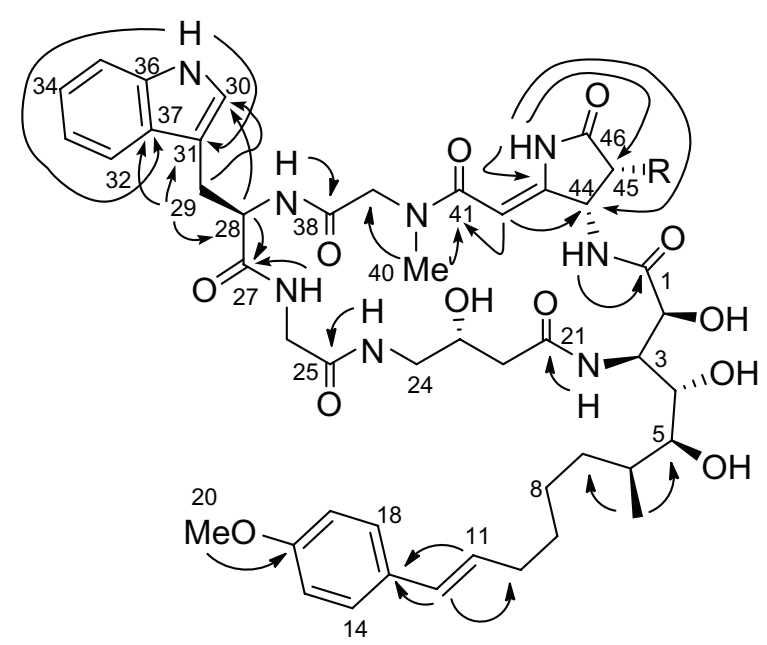

Figure 3. Key HMBC correlations for compounds I and 2.

\section{Publish your work in this journal}

Research and Reports in Medicinal Chemistry is an international, peerreviewed, open access journal publishing original research, reports, reviews and commentaries on all areas of medicinal chemistry. The manuscript management system is completely online and includes a very quick and fair peer-review system, which is all easy to use.
Visit http://www.dovepress.com/testimonials.php to read real quotes from published authors. 